\title{
Effect of some soil amendments on yield and quality traits of sugar beet (Beta vulgaris L.) under water stress in sandy soil
}

\author{
Mohamed S. Abbas ${ }^{\#}$ Amira Sh. Soliman, Zeinab R. Moustafa* and Kenawy M. \\ Abd El-Reheem* \\ Natural Resources Department, Institute of African Research and Studies, Cairo \\ University and "Physiology \& Chemistry Department, Sugar Crops Research Institute, \\ Agriculture Research Center, Giza, Egypt.
}

\begin{abstract}
$\mathbf{T}$ O STUDY the ability of soil amendments treatments for improving sugar beet quality and yield with reduce quantities of mineral nitrogen fertilizer under water stress. Two field experiments were carried out at Wadi El-Natrun, El-Beheira Governorate, Egypt, during 2014/2015 and 2015/2016 growing seasons. Compost and bentonite as soil amendments solely or mixed and two nitrogen rates (216 and 288 $\mathrm{kg} \mathrm{N} / \mathrm{ha}$ ) under water stresses $(100,75$ and $50 \%$ of irrigation water requirements, IWR) using a drip irrigation system were applied. The obtained results showed that increasing water stress up to $50 \%$ of water requirement significantly decreased sugar lost in molasses, root and sugar yields. While, it increased sucrose $\%$ and sugar extractable. Decrease nitrogen fertilizer from $100 \%$ to $75 \%$ of recommended rate $(288$ $\mathrm{kg} \mathrm{N} / \mathrm{ha}$ ) significantly decreased root and sugar yields, however, increased sucrose $\%$ and sugar extractable. Application of 12 ton/ha compost or bentonite as well as mixed 6 ton/ha of each of them led to a significant increase in all studied traits. Compost followed by bentonite was the best treatments. The maximum values of root and sugar yields were produced from the interaction between irrigation without water stress and fertilization by 216 or $288 \mathrm{~kg} \mathrm{~N} / \mathrm{ha}$ and application of $12 \mathrm{ton} / \mathrm{ha}$ compost in the second season.
\end{abstract}

Keywords: Bentonite, Compost, Nitrogen, Sugar beet, Sandy soil, Water stress.

\section{Introduction}

Sandy soils are described by low fertility and holding water capacity (Goa et al., 1998). Sandy soil as Wadi El-Natrun area could be considered as one of the encouraging areas for agricultural expansion but a lot of hydrological problems face many reclamation projects in Wadi ElNatrun area. Therefore, great efforts and many investigations have been carried out taking into consideration, avoiding the different side effects of development. Sugar-beet (Beta vulgaris L.) is a drought resistant crop that could produce a valuable yield even with declines irrigation (Winter, 1980). Sugar beet can be grown in a wide range of environment conditions and is noted for its tolerance to salinity and adapted to water stress (Monreala et al., 2007). The global climate change next to the limited water components are the most important factors at all in the field of crop production. Due to increasing use water cost and decreased available water in these regions, water stress has been the center of much attention (Winter, 1980). Drip irrigation one of the modern irrigation methods which have a significant role in increasing water use efficiency. Sharmasarkar et al. (2001) reported that sugar beet yield and sucrose content were better under drip irrigation system. Mahmoodi et al. (2008) showed that 70\% of field capacity was the best soil-water content which provided the highest values of yields. Also, Masri et al. (2015) revealed that the maximum values of quality traits were recorded in drip irrigated sugar beet with $75 \%$ of IWR.

Nitrogen is the most important elements in sugar beet productivity and the production extensively reduced to half due to decline of nitrogen fertilizer in soil (Cooke \& Scott, 1993). Mahmoud \& Masri (2009) reported that the dose

"Corresponding author email: msaelsarawy@yahoo.com

DOI: 10.21608/agro.2018.2660.1091

C2018 National Information and Documentation Center (NIDOC) 
of nitrogen (160 kg N/fad) significantly increased root weight ( 8.34 ton/fad) in both seasons. Masri et al. (2015) reported that increasing nitrogen fertilizer levels from 60 up to $120 \mathrm{~kg} \mathrm{~N} /$ fad significantly increased the root yield in both seasons and white sugar yield (ton/fad) only in the first season. ElHassanin et al. (2016) found that decreasing nitrogen fertilization level from $90 \mathrm{~kg}$ to $36 \mathrm{~kg} /$ fad significantly decreased sucrose $\%$, sugar lost in molasses, extractability percentage and yields ton/fad in both seasons of sugar beet. Also, AbdelMotagally (2016) concluded that the nitrogen dose at three folds of plant growth stages lead to raise the yield and quality of sugar beet.

Compost as an organic soil amendment is a main source of humans, which found as resulted of organic material decomposition. Compost is improves the soil physical and chemical properties and increasing water holding capacity. Wallace \& Carter (2007) showed that the using of compost increases soil fertility which led to increasing sugar beet root yield by $7 \%$. Mahmoud et al. (2014) found that adding of compost ( 2 ton/fad) gave the maximum values of root yield, as well as improved juice quality traits of sugar-beet. Also, application 12 ton/ha of compost with drip irrigation system improved root yield of sugar-beet (Masri et al., 2015).

Bentonite as an inorganic soil amendment is a rock containing clay minerals (Tawfiq, 2009) and has been documented in several countries as good amendments to increase the properties of such infertile sandy soil (Satje \& Nelson, 2009). Bentonite can significant increases cation exchange capacity (CEC) in soil as a source of negative charge as well as the availability of nutrients, enhancing agricultural productivity and improving fertilizer use efficiency (Noble \& Suzuki, 2005). Anas et al. (2009) found that the application of composts and bentonite led to the best use efficiency of available water and nutrients for maximizing growth and yield of peanut. Reguieg et al. (2011) and Hassan $\&$ Mahmoud (2013) showed that the application of bentonite increased the growth and yield of faba bean and corn. Shaheen et al. (2013) showed that adding of bentonite in sandy soil had a significant effect on yield and quality of potato. Eldardiry \& Abd El-Hady (2015) found that the increasing bentonite rates from 0 to $8 \%$ revealed increasing of barley grains and straw. Therefore, under the current circumstances and future, it has become the mandatory application of the appropriate methods to conserve water and reduce chemical inputs in the field of crop production. The aim of this work is to study the effect of organic and inorganic soil amendments on yield, and quality traits of sugar beet in sandy soil under water stress.

\section{Materials and Methods}

Two field experiments were conducted at Wadi El-Natrun (30 23' 19.89" N latitude, $30^{\circ}$ $21^{\prime} 41.06^{\prime \prime}$ E longitude and the latitude is 17.98 $\mathrm{m}$ above the sea), El-Beheira Governorate, Egypt during 2014/2015 and 2015/2016 growing seasons to study the effect of some soil amendments on quality and yield of sugar beet plant under water stress using a drip irrigation system.

\section{Materials \\ Soil samples}

The experimental soil samples were collected from two successive depths $(0-30 \mathrm{~cm})$ and $(30-$ $60 \mathrm{~cm}$ ) from soil surface before cultivation to determine some physical and chemical properties of soil according to Chapman \& Pratt (1961) and the description was given in Table 1. However, data in Table 1 illustrate some physical and chemical characteristics of the experimental soil. As shown in this table, soil texture is considered a sandy, where the mean of the two seasons were over $90 \%$ sand, $2.0 \%$ silt and $5.24 \%$ clay. The soil $\mathrm{pH}$ was alkaline (8.00). The analysis also illustrate that soil is non saline where electrical conductivity (EC) was $1.45 \mathrm{dSm}^{-1}$ less than $4 \mathrm{dSm}^{-1}$. Soil organic matter content was poor $(0.13)$.

\section{Irrigation water samples}

Chemical characteristic irrigation water is shown in Table 2. As shown in this table, the soil $\mathrm{pH}$ was (7.10) and electrical conductivity (EC) was recorded $\left(2.10 \mathrm{dSm}^{-1}\right)$. It shows that this soil has permissible saline.

\section{Sugar beet seeds}

Multi-germ variety Beta Poly Tery imported from Hungary was sown on October, $30^{\text {th }}$ in the first season and November, $1^{\text {st }}$ in the second season.

\section{Treatments}

the experiment included 24 treatments, represented a combination between three water levels 100, 75 and $50 \%$ of irrigation water requirement (IWR), four soil amendment treatments (without, 12 ton/ha compost, 12 ton/ ha bentonite and 6 ton/ha compost +6 ton/ha bentonite) and two nitrogen fertilizer levels 100 and $75 \%$ of recommending rate $(288 \mathrm{~kg} \mathrm{~N} / \mathrm{ha})$. 
TABLE 1. Soil physical and chemical properties of the experimental soil site.

\begin{tabular}{|c|c|c|}
\hline Soil analysis & 2014 & 2015 \\
\hline \multicolumn{3}{|c|}{ Particular size distribution (\%) } \\
\hline Coarse sand & 53.40 & 56.30 \\
\hline Fine sand & 39.36 & 32.46 \\
\hline Silt & 2.00 & 2.00 \\
\hline Clay & 5.24 & 9.24 \\
\hline Texture class & Sandy & Sandy \\
\hline $\mathrm{EC}(\mathrm{ds} / \mathrm{m})$ & 2.1 & 1.95 \\
\hline pH (soil paste) & 7.90 & 8.10 \\
\hline Organic matter $(\%)$ & 0.23 & 0.34 \\
\hline \multicolumn{3}{|c|}{ Soluble anions $(\mathrm{mg} / \mathrm{L})$} \\
\hline $\mathrm{CO}_{3}$ & - & - \\
\hline $\mathrm{HCO}_{3}$ & 1.00 & 1.20 \\
\hline $\mathrm{Cl}$ & 10.30 & 11.50 \\
\hline $\mathrm{SO}_{4}$ & 8.70 & 9.47 \\
\hline \multicolumn{3}{|c|}{ Soluble cations $(\mathrm{mg} / \mathrm{L})$} \\
\hline $\mathrm{Ca}$ & 6.40 & 7.20 \\
\hline $\mathrm{Mg}$ & 7.20 & 6.80 \\
\hline $\mathrm{Na}$ & 11.1 & 5.70 \\
\hline $\mathrm{K}$ & 0.70 & 0.37 \\
\hline \multicolumn{3}{|c|}{ Macronutrients (ppm) } \\
\hline $\mathrm{N}$ & 30.00 & 25.00 \\
\hline $\mathrm{P}$ & 20.00 & 22.00 \\
\hline $\mathrm{K}$ & 220.00 & 128.00 \\
\hline $\mathrm{Fe}$ & 2.14 & 3.40 \\
\hline $\mathrm{Cu}$ & 0.24 & 0.54 \\
\hline $\mathrm{Zn}$ & 1.9 & 2.5 \\
\hline $\mathrm{Mn}$ & 4.4 & 4.0 \\
\hline
\end{tabular}

TABLE 2. Chemical characteristic of irrigation water.

\begin{tabular}{|c|c|c|c|c|c|c|c|c|c|}
\hline \multirow{2}{*}{$\begin{array}{c}\mathbf{E C} \\
(\mathrm{ds} / \mathrm{m})\end{array}$} & \multirow[t]{2}{*}{ pH } & \multicolumn{4}{|c|}{ Soluble anions (mg/L) } & \multicolumn{4}{|c|}{ Soluble cations (mg/L) } \\
\hline & & $\mathrm{CO}_{3}$ & $\mathrm{HCO}_{3}$ & $\mathbf{C l}$ & $\mathrm{SO}_{4}$ & $\mathbf{C a}$ & $\mathrm{Mg}$ & $\mathbf{N a}$ & $\mathbf{K}$ \\
\hline 1.85 & 7.10 & - & 3.6 & 3.75 & 9.84 & 4.22 & 4.47 & 6.40 & 2.10 \\
\hline
\end{tabular}

Application of chemical fertilizations and soil amendments

compost and bentonite were added before sowing. Thinning process was done to one plant/hill at 4 leaf stage (after 2 weeks from sowing). Nitrogen fertilizer was added in the form of ammonium nitrate $(33.5 \% \mathrm{~N})$ in three equal doses; the first was applied after thinning and the second and third were added at one and two months later. Phosphorus was added in the form of super-phosphate (15.5\% $\mathrm{P}_{2} \mathrm{O}_{5}$ ) at rate $72 \mathrm{~kg} /$ ha before sowing and during land preparation. Potassium was added in the form of potassium sulfate $\left(48 \% \mathrm{~K}_{2} \mathrm{O}\right)$ at the rate $115.2 \mathrm{~kg} / \mathrm{ha}$ with the first dose of nitrogen. The chemical analysis of applied bentonite and compost are presented in Tables 2 and 3.

\section{Application of irrigation water}

Drip irrigation system was done through narrow tubes that deliver water directly to the base of the plant and irrigation water used in the experiment was pumped from a well. The amounts of applied water for the three water stress (average of two growing seasons) were $6012,4664.4$ and $3172.8 \mathrm{~m}^{3} \mathrm{ha}^{-1}$ for 100,75 and $50 \%$ of (IWR), respectively. Amount of irrigation water requirements was determined using Blany \& Criddle (1962) method and its chemical analysis is given in Table 4. 
TABLE 3. Chemical analysis of Compost (\%).

\begin{tabular}{|c|c|c|}
\hline Compost analysis & Unit & Concentration \\
\hline Weight of $\mathrm{m}^{3}$ & $\mathrm{~kg}$ & 680 \\
\hline Moisture content & $\%$ & 16.60 \\
\hline $\mathrm{pH}$ & & 7.86 \\
\hline $\mathrm{EC}$ & $\mathrm{ds} / \mathrm{m}$ & 4.46 \\
\hline Ammonium nitrogen & ppm & 141 \\
\hline Nitrate nitrogen & ppm & 19.60 \\
\hline Total nitrogen & $\%$ & 1.03 \\
\hline Organic matter & $\%$ & 31 \\
\hline Organic carbon & $\%$ & 17.50 \\
\hline Ashes & $\%$ & 69 \\
\hline $\mathrm{C} / \mathrm{N}$ ratio & & $1: 17$ \\
\hline Total phosphoric & $\%$ & 1.25 \\
\hline Total potassium & $\%$ & 1.34 \\
\hline Weed seeds & & Not found \\
\hline Nematode & larva/200 gm & Not found \\
\hline Fecal coliform & cell/gm & Not found \\
\hline Salmonella bacterium & cell/gm & Not found \\
\hline
\end{tabular}

TABLE 4. Chemical analysis of bentonite (\%).

\begin{tabular}{|c|c|c|c|c|c|c|c|c|c|c|c|}
\hline \multirow{2}{*}{ O.M } & \multirow{2}{*}{$\begin{array}{l}\mathrm{CaCO}_{3} \\
(\mathrm{~g} / \mathrm{kg})\end{array}$} & \multirow{2}{*}{$\begin{array}{l}\mathrm{CaSO}_{4} \\
(\mathrm{~g} / \mathrm{kg})\end{array}$} & \multirow{2}{*}{$\begin{array}{c}E C \\
(\mathrm{ds} / \mathrm{m})\end{array}$} & \multirow{2}{*}{$\mathbf{p H}$} & \multicolumn{3}{|c|}{ Soluble anions $(\mathrm{mg} / \mathrm{L})$} & \multicolumn{4}{|c|}{ Soluble cations (mg/L) } \\
\hline & & & & & $\begin{aligned} & \mathrm{CO}_{3}^{--} \\
&+ \mathrm{HCO}_{3}^{-} \\
&\end{aligned}$ & $\mathrm{Cl}^{-}$ & $\mathrm{SO}_{4}^{--}$ & $\mathrm{Ca}++$ & $\mathbf{M g}++$ & $\mathrm{Na}+$ & $\mathbf{K}+$ \\
\hline nil & 149.1 & 3.6 & 3.9 & 7.10 & 0.24 & 0.59 & 1.34 & 0.79 & 0.27 & 1.95 & 0.02 \\
\hline
\end{tabular}

Quality traits and yield measurements

At harvest (180 days from sowing), the three guarded central rows of each plot were harvested and cleaned to determine the following traits in both seasons.

\section{Juice quality}

1-Sucrose percentage was determined by using Saccharometer according to Carruthers \& Oldfield (1960).

2-Sugar lost in molasses (SM\%)

Sugar lost in molasses $=0.14(\mathrm{~V} 1+\mathrm{V} 2)+0.25$ (V3) +0.50 (Devillers, 1988).

\section{3-Sugar extractable (\%)}

Sugar extractable =V4-SM-0.6 (Dexter et al., 1967)

where: $\mathrm{V}_{1}=$ Sodium. $\mathrm{V}_{2}=$ Potassium. $\mathrm{V}_{3}=\alpha$-amino N. $\mathrm{V}_{4=}=\mathrm{Pol}_{\%}$

\section{Yields}

1- Top yield (ton/ha).

2- Root yield (ton/ha).

3- Sugar yield (ton/ha)

Sugar yield $=$ Root yield (ton/ha) $\mathrm{x}$ Sugar extraction $\%$. 


\section{Experimental design and statistical analysis}

A split-split plot design with three replications was done. The experiment included 24 treatments, represented the combination among three water stress occupied the main plots, four soil amendments allocated in the sub plots and two nitrogen levels were randomly distributed in the sub-sub plots. Each sub-sub plot area was $10.5 \mathrm{~m}^{2}, 5$ ridges, $3.5 \mathrm{~m}$ long and $60 \mathrm{~cm}$ apart and spacing between hills were 20 $\mathrm{cm}$. All data were exposed to statistical analysis. The least significant differences (LSD) values at 5\% level of probability according to Snedecor \& Cochran (1989).

\section{Results and Discussion}

Juice quality

\section{Effect of water stress}

According to Tables 5 and 6, irrigated sugar beet with $100 \%$ of IWR gave significantly the minimum sucrose percentage (17.56 and $17.73 \%$ ) in both seasons. After which irrigation with $75 \%$ of IWR with the average sucrose (17.93\% and $18.05 \%)$ were the second rank and increasing water stress to $50 \%$ of IWR with (18.56 and $18.50 \%$ ) had the maximum sucrose the third one. There was a significant difference between the levels $100 \%$ and $75 \%$ of IWR and also between these two levels and water stress at $50 \%$ of IWR. These results are in harmony with obtained by Abyaneh et al. (2017) who reported that the increasing of nitrogen and irrigation water applications reasons a decrease in the sugar content.

Sugar lost in molasses and sugar extractable percentages had the same trend where the highest values recorded 1.90 and $16.06 \%$ in the first season and 2.17 and $15.73 \%$ in the second season, respectively were detected from irrigated by $50 \%$ of IWR. The results are similar to Esmaeili (2011) and Masri et al. (2015). Furthermore, Kaur et al. (2007) reported that, under water shortage, the higher sucrose content accompanied by higher sugar phosphate synthetase and lower acid invertase activities in roots.

\section{Effect of nitrogen rates}

Decreasing nitrogen fertilizer rate from 100\% to $75 \%$ of recommended rate tended to significantly increase the sucrose \% from 17.85 to $18.18 \%$ and 17.97 to $18.22 \%$ in the two seasons, respectively and sugar extractable from 15.40 to $15.83 \%$ and 15.26 to $15.58 \%$. On the other hand, decreasing nitrogen from 100 to $75 \%$ of recommended rate significantly decreased sugar lost in molasses from 1.84 to $1.76 \%$ and 2.11 to $2.04 \%$ in two seasons, respectively (Tables 5 and 6).
The decrease in sucrose \% owing to increasing nitrogen fertilizer level can be attributed to its role in increasing impurities such as $\alpha$-amino acid and hence increasing sugar lost in molasses thus decreasing sucrose content in roots. The results are similar to Esmaeili (2011). Previously, Milford \& Watson (1971) showed that nitrogen fertilizer increased the fraction of the assimilate entering the root that was used in plant growth at the expense of that stored as sugar. Also, Weeden (2000) explained that with an increase of nitrogen in soil, amino acid in root increases that it causes sugar crystallization and so decreasing of extractable sugar.

\section{Effect of some soil amendments}

Soil amendments under study significantly increased sucrose $\%$, sugar lost in molasses $\%$ and sugar extractable $\%$ in the two seasons as compared to control (without soil amendments) (Tables 5 and 6). Application of $12 \mathrm{ton} / \mathrm{ha}$ compost or bentonite gave the maximum values of sucrose 18.92 and $18.36 \%$ in the first season and 18.58 and $18.75 \%$ in the second season. Data on hand revealed that no significant differences between the application of compost or bentonite were observed in both seasons. Data also found that there was no significant difference between compost and bentonite or compost + bentonite for sugar lost in molasses $\%$ in both seasons. Regarding sugar extractable \%, the addition of 12 ton/ha compost gave the highest value $16.45 \%$ in the first season. While in the second season the highest value was $16.06 \%$ produced from the addition of 12 ton/ha bentonite to the soil. This finding agreed with obtaining by of Kabil et al. (2015). However, compost led to increasing of photosynthetic process and leaf area which revealed in increase sugar production (Molnou et al., 2008). Moreover, bentonite plays a significant role in providing plants with needs of sufficient water and nutrients that should recover to form good quality (Eldardiry \& Abd El-Hady, 2015).

\section{Effect of interactions}

The first order interaction: Water deficient and nitrogen rates interaction significantly effected sucrose and sugar lost in molasses but sugar extractable didn't significantly affect in the two seasons. The highest values of sucrose $\%$ were produced from beet irrigated by $50 \%$ of water requirement and addition of nitrogen at $75 \%$ of the recommended rate. Data also, found that the best interaction gave the lowest sugar lost in molasses was resulted from $100 \%$ of IWR and fertilization of nitrogen at $75 \%$ of the recommended rate in the two seasons. 


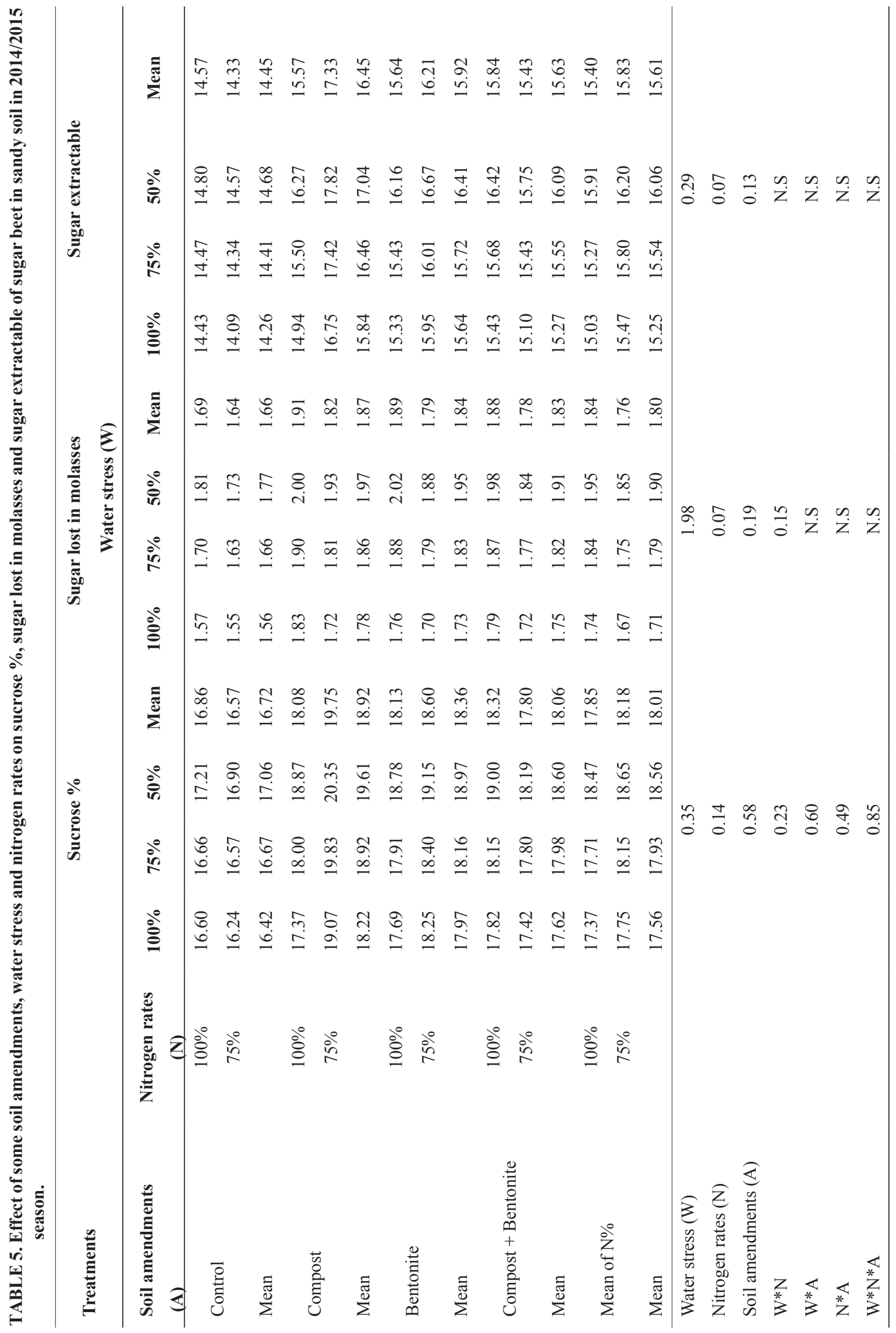

Egypt.J.Agron. Vol. 40, No. 1 (2018) 


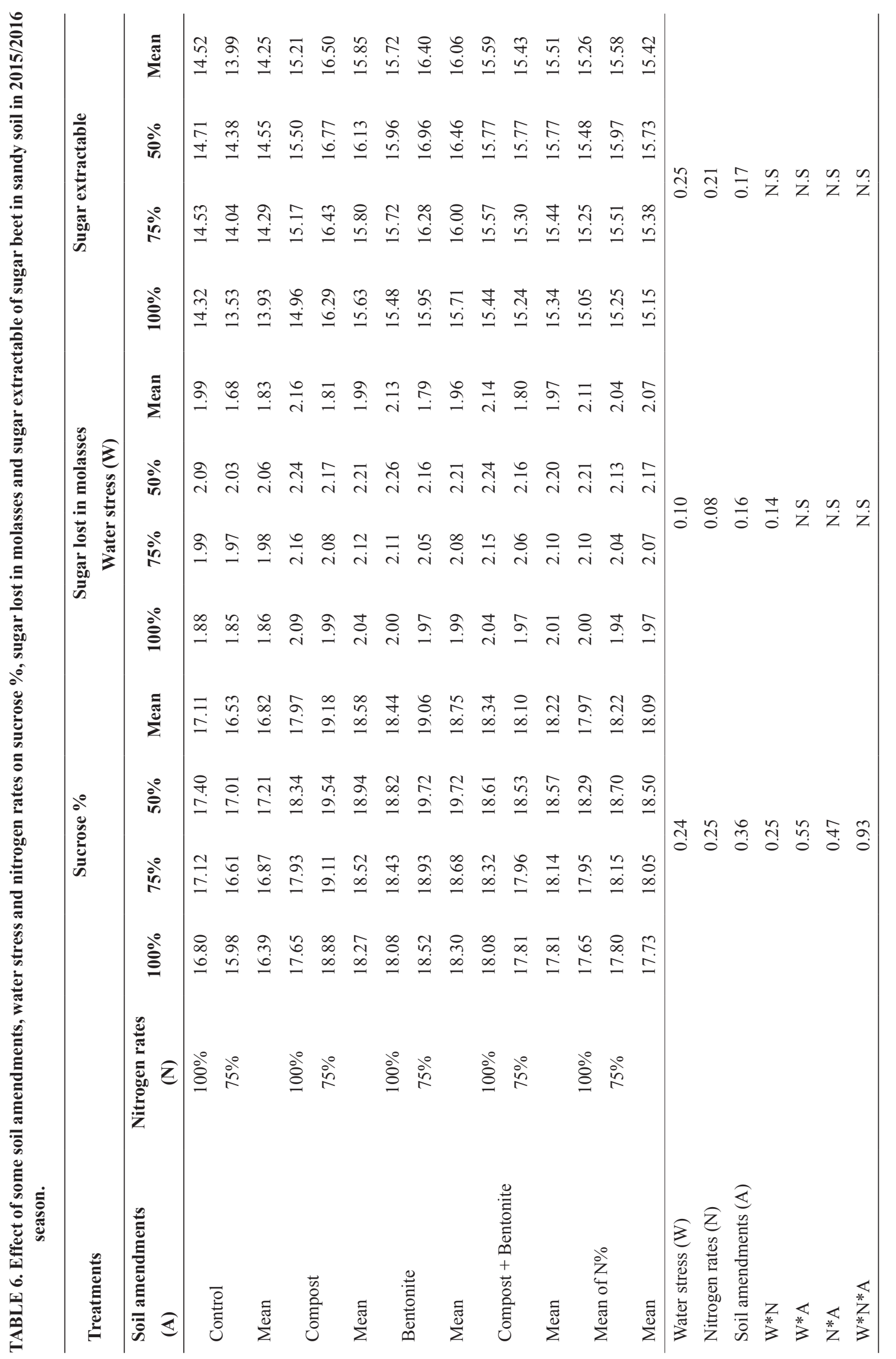

Egypt.J.Agron. Vol. 40, No. 1(2018) 
The interaction between water deficient and soil amendment was significantly only on the sucrose $\%$ in both seasons. The best interaction gave the highest values of sucrose $\%$ was produced from irrigation by $50 \%$ of IWR and application of 12 ton/ha compost in the first season. While in the second season was from $50 \%$ IWR and 12 ton/ha bentonite.

Data also in Tables 5 and 6 found that sucrose $\%$ had a significant effect on the interaction between nitrogen rates and soil amendments in the two seasons. The highest values of sucrose $\%$ were recorded from application of 12 ton/ha of compost and addition of nitrogen at $75 \%$ of recommended rate followed by the same rate of nitrogen fertilizer and bentonite at 12 ton/ha (with significance level difference among).

The second order interaction: Sugar lost in molasses and sugar extractable \% didn't have a significant effect on the interaction between water deficient, nitrogen rates and soil amendments in the two seasons. While sucrose $\%$ had significantly affect where the highest values of sucrose $\%$ recording from $50 \%$ of IWR and nitrogen at $75 \%$ of recommended rate and application of 12 ton/ha compost in the first season. While, the same interaction, but added bentonite instead of compost gave the highest sucrose $\%$ in the second season.

\section{Yield characteristics}

Top and root yield (ton/ha)

Effect of water stress: Top and root yield significantly decreased by increasing water deficient from 100 to $50 \%$ of IWR in both seasons (Tables 7 and 8). The optimum irrigation was $100 \%$ of IWR where, it produced the highest values of top and root yield recorded 23.02 and 61.08 ton/ha, respectively, in the first season as well as 21.94 and 63.36 ton/ha in the second seasons. On the contrast, the lowest means of the top and root yields were achieved when irrigated by $50 \%$ of IWR. It is important to mention that there were three significant differences between levels of irrigation water requirement under study in both seasons.

The decreases of top and root yield have been detected as water deficiency is related to decreasing pressure potential stomata conductivity and relative water content of leaf that cause lower growth which, led to decrease yield. The results are similar to Esmaeilli (2011) and Masri et al. (2015).
Effect of nitrogen rates: The data in Tables 7 and 8 showed that decreasing nitrogen rates from 100 to $75 \%$ of recommended rate significantly decreased top yield from 23.35 to 19.42 and from 23.21 to 19.34 ton/ha in the two seasons, respectively. Regarding root yield, the significant decrease was from 57.14 to 52.54 and 58.51 to 54.65 ton/ha. These results may be due to that nitrogen has a vital role in building up metabolites, activating enzymes and carbohydrates accumulation which transferred from leaves to developing root which in turn enhanced root length, diameter, and fresh weight finally roots yield per unit area. Similar findings were reported by Ramadan et al. (2003) and ElHassanin et al. (2016).

Effect of some soil amendments: Compost and bentonite as an individual or together significantly increased top and root yields as compared with control (without soil amendments) in both seasons (Tables 7 and 8). Application of 12 ton/ha compost recorded the highest values of top and root yields ton/ha since results were 25.32 and 60.72 ton/ha, respectively, in the first season and 24.53 and 62.4 ton/ha in the second seasons. The second rank was the application of 12 ton/ha bentonite where it recorded 21.98 and 56.59 ton/ha for the top and root yields, respectively, as well as 21.41 and 57.55 ton/ha in both seasons, respectively (with the significance level difference between them). Such positive effect may be due to that compost increases the capacity of soil water retention. It also increases cation exchange capacity of the soil, therefore, increases its ability to retain nutrients which promote the development of root systems. Bentonite also could raise the storage capacities of soil for water and fertilizer, which led to the maximum growth and yield (Iskander et al., 2011). The same trend was found by Reguieg et al. (2011) and Youssef (2013).

\section{Effect of interactions}

The first order interaction: Referring the effect of the interaction between water deficient and nitrogen rates on top and root yields, it was significant in two seasons. The highest averages of root yield were observed when the sugar beet irrigated by $100 \%$ of IWR and addition of nitrogen at $100 \%$ of the recommended rate in both seasons. Meanwhile, sugar beet irrigated by $100 \%$ of IWR and fertilized by nitrogen at $75 \%$ of recommended rate occupied the second rank. 


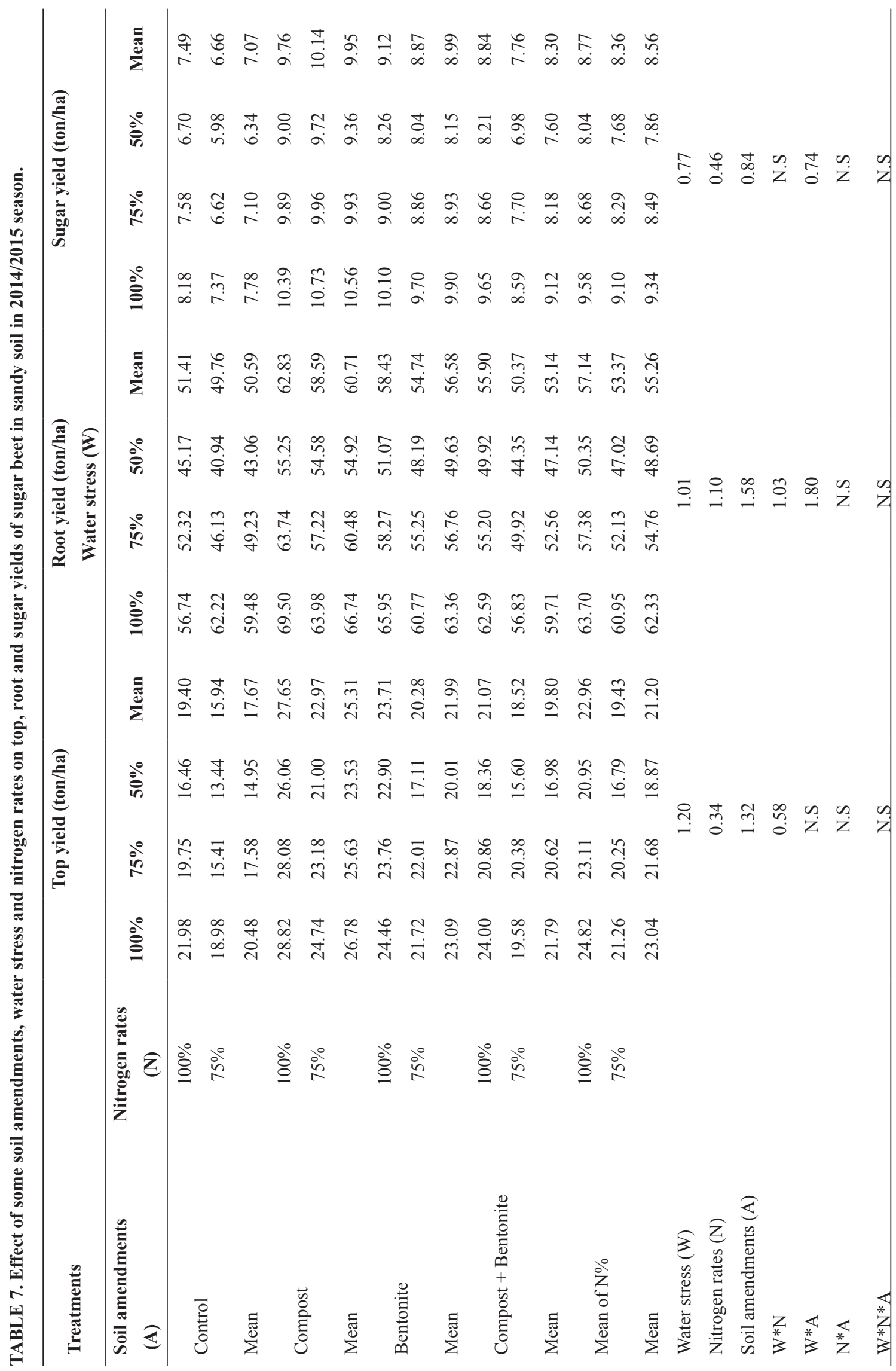




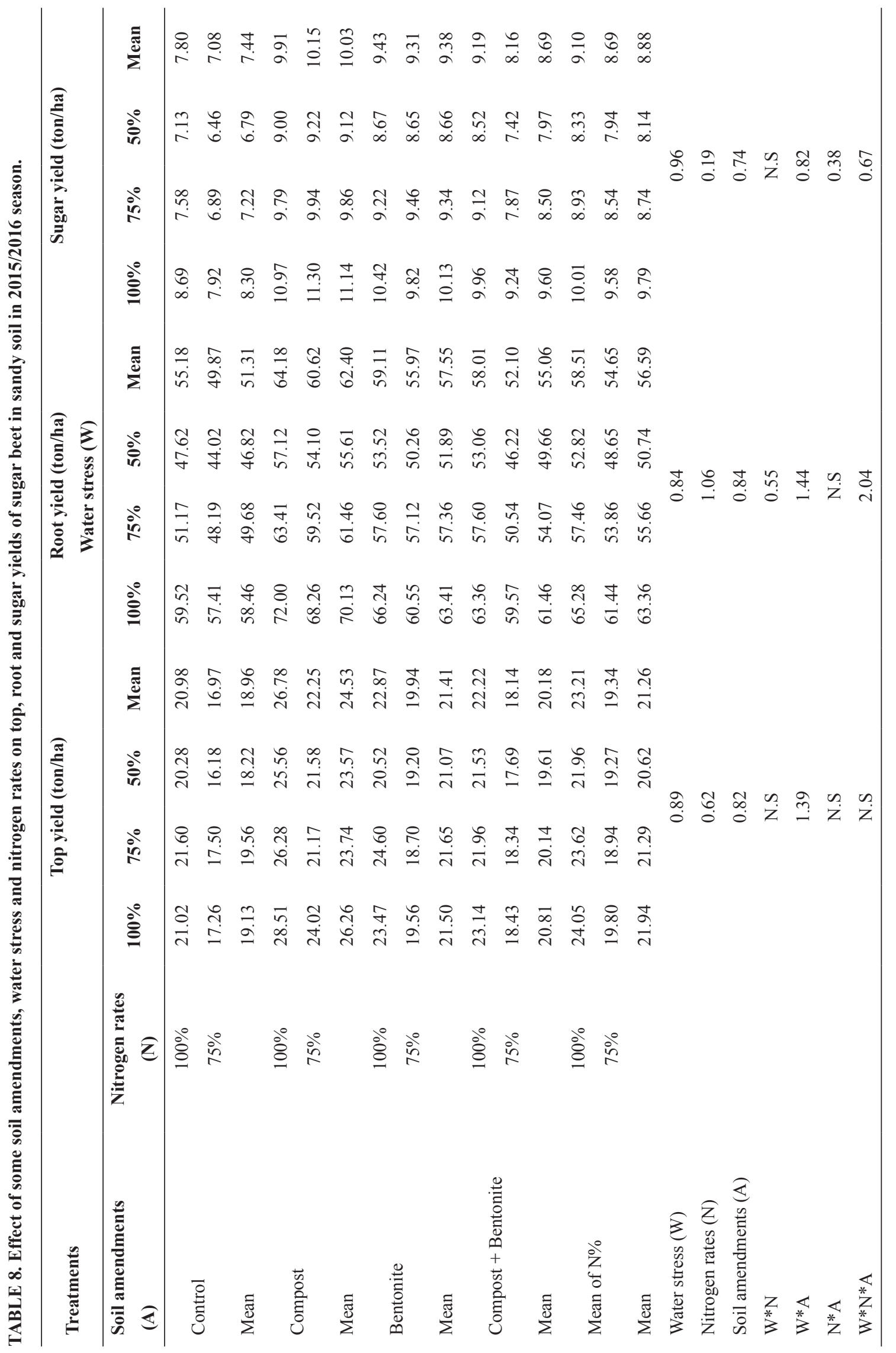

Egypt.J.Agron. Vol. 40, No. 1 (2018) 
The response of root yield to the interaction between water deficient and soil amendment was significant in two seasons. It can be considered that the highest values of root yield were obtained due to irrigation by $100 \%$ of IWR and application of $12 \mathrm{t} / \mathrm{ha}$ of compost followed by the same IWR and treated by $12 \mathrm{t} / \mathrm{ha}$ bentonite in both seasons. The interaction between nitrogen rates and soil amendment did not significantly effect on top or root yields in both seasons.

The second order interaction: Water deficient, nitrogen rates and soil amendments interaction had a significant effect on root yield in the second season only. The maximum value of root yield was produced from irrigation by no water stress and application of $12 \mathrm{t} / \mathrm{ha}$ compost with added nitrogen at $100 \%$ of the recommended rate. Sugar yield (ton/ha)

\section{Effect of water stress}

Results in Tables 7 and 8 showed that irrigated sugar beet by $100 \%$ of IWR with sugar yield 9.34 and 9.79 ton/ha had the maximum yield in the two seasons, respectively. After which irrigation with $75 \%$, then $50 \%$ of IWR with average sugar yield of 8.52 and 7.85 ton/ha in the first season as well as 8.74 and 8.14 ton/ha in the second season. It is important to note that there wasn't a significant difference between the levels at $100 \%$ and $75 \%$ of IWR, but there was significant between irrigation by 100 and $50 \%$ of IWR in both seasons. The decrease sugar yield by increasing water stress may be attributed to highly decrease in root yield although; increase sugar extractable. The results are similar to Masri et al. (2015). On other hand, Mahmoud et al. (2018) reported that 30-50\% from field capacity as water stress may be suitable for high yield of sugar beet

\section{Effect of nitrogen fertilizer}

Decreasing nitrogen fertilizer rate from 100 to $75 \%$ of recommended rate tended to significant decrease sugar yield from 8.78 to 8.35 ton/ha and 9.53 to 8.69 ton/ha in both seasons, respectively (Tables 7 and 8). The increase in sugar yield per unit area due to the application of nitrogen can be explained by the fact that nitrogen has a vital role in improving all growth attributes and root weight, consequently increasing sugar yield per unit area. These results are agree with those stated by Ramadan et al. (2003) and El-Hassanin et al. (2016). On other hand, Marajan et al. (2017) found that compost and nitrogen treatments alone showed significant differences in sugar beet root fresh and dry weights.

\section{Effect of soil amendments}

All soil amendments under study significantly increased sugar yield as compared to control (without soil amendment) in both seasons (Tables 7 and 8). Application of 12 ton/ha compost or bentonite had the maximum sugar yield were, there was no significant difference between them. The highest amounts of sugar yield were 9.94 and 8.98 ton/ha in the first season and 10.03 and 9.38 ton/ha in the second season, for compost and bentonite, respectively. The increase of sugar yield by application of compost or bentonite may be due to that it's role in increase each of root yield and sugar extractable as mentioned before. This finding agreed with obtained by of Kabil et al. (2015).

\section{Effect of interactions}

The first order interaction: There were no significant differences between water deficient and two nitrogen rates interactions on sugar yield ton/ha in the two growing seasons. This may be due to the individual effect of each factor.

Sugar yield ton/ha was affected significantly by the interaction between water deficient and soil amendments in both seasons. The highest values were obtained from the application of compost or bentonite with irrigation by $100 \%$ of IWR in both seasons. On the other hand, the lowest values resulted from control (without soil amendment) and $50 \%$ of IWR.

The response of beet sugar yield to the interaction between two nitrogen rates and soil amendments was significant in the second season only. The highest values of sugar yield were recorded from the application of 12 ton/ha compost and dressing of nitrogen at $75 \%$ or $100 \%$ of the recommended rate.

The second order interaction: The effect of the interaction among all factors under study on sugar yield was significant in the second season. The highest values of sugar yield were produced from the interaction between without water stress and the addition of nitrogen at $75 \%$ of recommended rate and treated soil by 12 ton/ha compost. On the other hand, the lowest value was produced as a result of irrigation by $50 \%$ of IWR and fertilization by nitrogen at $75 \%$ of recommended rate and without soil amendments.

\section{Conclusion}

The highest values of sugar yield were produced from interaction between nitrogen addition at 
$75 \%$ of recommended rate and treated soil by 12 ton/ha compost and without water stress. On the other hand, the lowest value was produced as result of irrigation by $50 \%$ of irrigation water requirements and fertilization by nitrogen at $75 \%$ of recommended rate and without soil

\section{References}

Abdel-Motagally, F.M.F. (2016) Response of sugar beet cultivars to the application level and time of nitrogen fertilizer. J. Agric. Sci. 47(1), 1-13.

Abyaneh, H.Z., Jovzi, M. and Albaji, M. (2017) Effect of regulated deficit irrigation, partial root drying and $\mathrm{N}$-fertilizer levels on sugar beet crop (Beta vulgaris L.). Agricultural Water Management, 194, 13-23.

Anas, A.W., Abd El Aty, M.I. and Mohamed, A.B. (2009) Integrated input soil and water managements in maximizing peanut crop under the eastern drought-front desert outskirt of El Fayoum Governorate, Egypt. J. Agric. \& Biol. Sci. 5(1), 1-15.

Blaney, H.F. and Criddle, W.D. (1962) Determining consumptive use and irrigation water requirements, USDA Technical Bulletin 1275. US Depart.Agric. Beltsville., 59.

Carruthers, A. and Oldfield, J.E.T. (1960) Methods for the assessment of beet quality. Int. Sugar J. 63(1), 103-105.

Chapman, H.D. and Pratt, P.F. (1961) "Methods of Analysis for Soil, Plant and Water". Univ. California, Agric. Sci., $2^{\text {nd }}$ printing, pp. 150-179.

Cooke, D.A. and Scott, R.K. (1993) "The Sugar Beet Crop". Chapman and Hall London, pp. 262-265.

Devillers, P. (1988) Prevision du sucre melasse. Sucrerie Francases, 129, 190-200.

Dexter, S.T., Frankes, M.G. and Snyder, F.W. (1967) A rapid of determining extractable white sugar as may be applied to the evaluation of agronomic practices and grower deliveries in the sugar beet industry. $J$. Am., Soc., Sugar Beet Technol. 14, 433-454.

Eldardiry, E.I.E. and Abd El-Hady, M. (2015) Effect of different soil conditioners application on some soil characteristics and plant growth 1- soil moisture distribution, barley yield and water use efficiency. J.Agric. Sci. 4(7), 361-367.

El-Hassanin, S.M.R., Moustafa, N.S., Khalifa, A.M. and Ibrahim, N.I. (2016) Effect of foliar application with humic acid substance under nitrogen fertilization levels on quality and yields of sugar beet plant. Int. J. Curr. Microbiol. App. Sci. 5(11), 668-680.

Esmaeilli, M.A. (2011) Evaluation of the effects of water stress and different levels of nitrogen on sugar beet (Beta vulgaris). Int. J. Biol. 3(2), 89-93.

Goa, S., Pan, W.L. and Koeining, R.T. (1998) Integrated root system age in relation to plant nutrient uptake activity. Agron. J. 90, 505-510.

Hassan, A.Z.A. and Mahmoud, A.M. (2013) The combined effect of bentonite and natural zeolite on sandy soil properties and productivity of some crops. Topclass J. Agric. Res. 1(3), 22-28.

Iskander, A.L., Khald, E.M. and Sheta, A.S. (2011) Zinc and manganese sorption behavior by natural zeolite and bentonite. Ann. Agric. Sci. 56, 43-48.

Kabil, E.M., Makroum, F.M., Assobhei, K., Rafrafl, O., Loizidou, M. and Aajjane, A. (2015) Effect of compost made with sludge and organic residues on soil and sugar beet crop in Morocco. J. Agron. 14, 264-271.

Kaur, K., Gupta, A.K. and Kaur, N. (2007) Effect of water deficit on carbohydrate status and enzymes of carbohydrate metabolism in seedlings of wheat cultivars. Indian J. Biochem. 44, 223-230.

Mahmoodi, R., Maralian, H. and Aghabarati, A. (2008) Effects of limited irrigation on root yield and quality of sugar beet (Beta vulgaris L.). African J. Biotechnol. 7 (24), 4475-4478.

Mahmoud, E.A., Hassanin, M.A., Borham, T.I. and Emara, E.I.R. (2018) Tolerance of some sugar beet varieties to water stress. Agricultural Water Management, 31, 144-151.

Mahmoud, E.A. and Masri, M.I. (2009) Effect of nitrogen rates and its time of application on the productivity of sugar beet under sprinkler irrigation in newly reclaimed soils. J. Agric., Mansoura Univ. 34(8), 9037-9048.

Mahmoud, E.A., Ramadan, B.S.H., El-Geddawy, I. H. and Korany, S.F. (2014) Effect of mineral biofertilization on productivity of sugar beet. J. Plant Production, Mansoura Univ. 5(4), 699-710.

Malnou, C.S., Gaggard, K.W. and Sparkes, D.L. (2008) Nitrogen fertilizer and the efficiency of the sugar beet crop in late summer. Eur. J.Agron. 28, 47-56.

Marajan, W. A., Hadad, M. A., Gafer, M. O., Sulfab, 
H.A. and Ali, M. A. (2017) Effect of mineral and bio-organic fertilizers on sugar beet growth under semi-arid zone. International Journal of Science and Research, 6(9), 1020-1025.

Masri, M.I., Ramadan, B.S.B., El-Shafai, A.M.A. and El-Kady, M.S. (2015) Effect of water stress and fertilization on yield and quality of sugar beet under drip and sprinkler irrigation systems in sandy soil. Int. J. Agric. Sci. 5(3), 414-425.

Milford, G.F. and Watson, D.J. (1971) The effect of nitrogen on the growth and sugar content of sugar beet. Ann. Bot. 35, 287-300.

Monreala, J.A., Jimeneza, E.T., Remesala, E., MorilloVelardeb, R., Garcia-Maurinoa, S. and Echevarriaa, C. (2007) Praline content of sugar beet storage roots: Response to water deficit and nitrogen fertilization at field conditions. Enviro. and Exper. Botany, 60(2), 257-267.

Noble, A.D. and Suzuki, S. (2005) Improving the productivity of degraded cropping systems in northeast Thailand: Improving farmer practices with innovative approaches. In: Proceedings of the International Conference on Research Highlights and Vanguard Technology on Environmental Engineering in Agricultural System, Kanazawa, Japan, pp. 371-380.

Ramadan, B.S.H., Hassan, H.R. and Abdou, F.A. (2003) Effect of mineral and biofertilizers on photosynthetic pigments, root quality, yield components and anatomical structure of sugar beet (Beta vulgaris L.) plants grown under reclaimed soils. J. Agric. Sci. Mansoura, Univ. 28(7), 5139-5160.

Reguieg, H.Y., Belkhodja, M. and Chibani, A. (2011) Effect of bentonite on the sandy soil of arid regions: Study of behavior of an association of wheat and chickpea. J. of Environ. Sci. and Engineering, 5, 1668-1677.
Satje, A. and Nelson, P. (2009) Bentonite treatments can improve the nutrient and water holding capacity of sugarcane soils in the wet tropics. Proc. J. Sugar Cane International, 27(5), 183-188.

Shaheen, A.M., Rizk, F.A., Abd El-Samad, E.H. and El.-Ashry, S.M. (2013) Effect of nitrogen fertilizer and soil conditioner on the productivity of potato plants grown under sandy soil conditions. J. Appl. Sci. Res. 9(3), 1774-1781.

Sharmasarkar, F.C., Sharmasarkar, S., Held, L.J., Miller, S.D., Vance, G.F. and Duo, Z.R. (2001) Agroeconomic analysis of drip irrigation for sugar beet production. Agron. J. 93(3), 517-523.

Snedecor, G.W. and Cohran, W.G.(1989) "Statistical Method" $6^{\text {th }}$ ed., Iowa State Univ. Press, Amess, Iowa, USA., p. 593.

Tawfiq, A.J. (2009) Improvement of sandy soil properties by using bentonite. Kufa J. Eng. 1(1), 29-39.

Wallace, P. and Carter, C. (2007) Effects of compost on yields of winter wheat and barley, sugar beet, onion and swede in the fourth and fifth years of a rotation. Home Growth Cereals Authority Project Report. 422, 31pp.

Weeden, B.R. (2000) Potential of sugar beet on the Atherton Tableland. A Report for the Rural Industries Research and Development Corporation. December 2000, RIRDC Publication No 00/167. RIRDC Project No DAQ-211A.

Winter, S.R. (1980) Suitability of sugar beet for limited irrigation in a semi-arid climate. Agron. J. 72, 118-123.

Youssef, S.B.D. (2013) Effect of bentonite and zeolite ores on potato crop (Solanum tuberosum L.) under north Sinai conditions. J. Plant Production, Mansoura Univ. 4(12), 1843-1856.

(Received 16/ 1/2018; accepted 19 / 4 / 2018) 


\section{تأثير بعض محسنات التربة على إنتاجية وجودة بنجر السكر تحت الإجهاد المائي في الأراضي بولئ الرملية

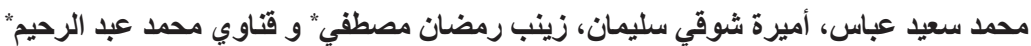

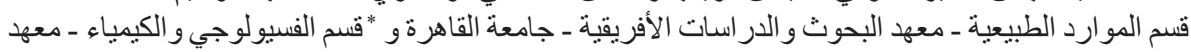

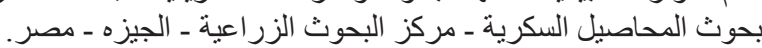

لار اسة ثاثثر المعاملة بمحسنات التربة لتحسين جودة وإنتاجية بنجر السكر وتقليل الأسمدة النتروجينية تحت ظروف الإجهاد المائي في الأراضي الرملية نم اجر اء تجربتين حقليتين خلال موسمي النمو

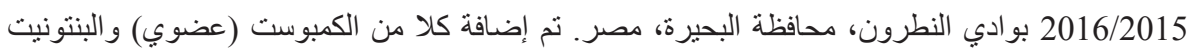

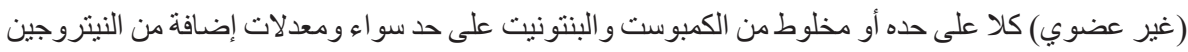

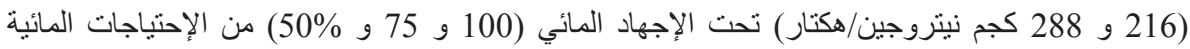

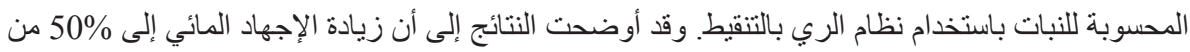

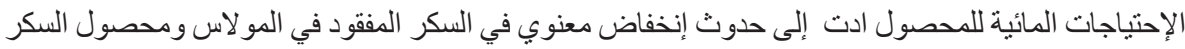

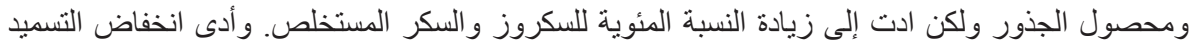

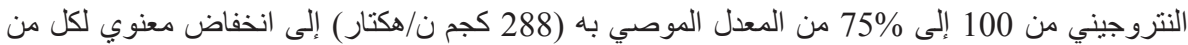

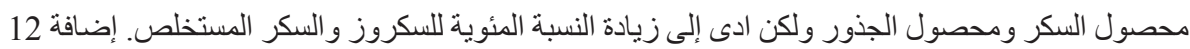

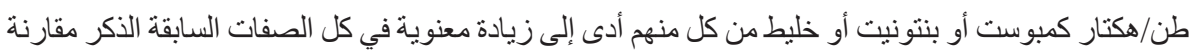

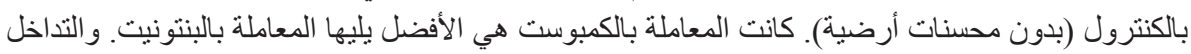

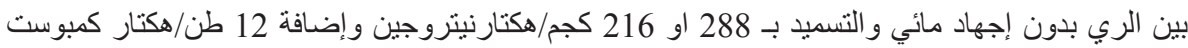

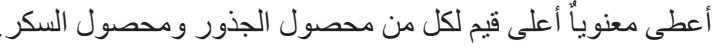

